\title{
IP-10 PROTEIN AT CHRONIC HEPATITIS C AND ITS ROLE IN FORECASTING TREATMENT OUTCOMES
}

\author{
Geyvandova N. I., Lipov A. V., Yagoda A. V., Frolova A. A. \\ Stavropol State Medical University, Russian Federation

\section{ПРОТЕИН ІР-10 ПРИ ХРОНИЧЕСКОМ ВИРУСНОМ ГЕПАТИТЕ С И ЕГО РОАЬ В ПРОГНОЗИРОВАНИИ РЕЗУАЬТАТОВ ТЕРАПИИ}

\author{
Н. И. Гейванаова, А. В. Аипов, А. В. ЯгоАа, А. А. Фролова \\ Ставропольский госуАарственный меАицинский университет, \\ Российская ФеАерация
}

Clinical values were identified for serum levels of $\gamma$ interferon-induced protein (IP-10) to be employed in forecasting SVR to AVT for $\mathrm{CHC}$, which was carried out involving 107 patients (50 females and 57 males); mean age $-43.0 \pm 11$ yrs. 75 of the patients were diagnosed with genotype $1 \mathrm{HCV}(\mathrm{G} 1)$, while 32 patients were identified as having non-1 genotype HCV (G2 or G3). The IP-10 levels in blood serum were detected with the ELISA method. Patients with CHC had significantly higher blood IP-10 levels compared to healthy people, and that depended on the aminotransferases' activity as well as on the stage of hepatic fibrosis. A standard AVT with pegIFN- $\alpha$ medications and ribavirin given to 52 patients with G1 (SVR $54.9 \%$ ) and 27 - with G2 or G3 (SVR $75 \%$ ), showed that the patients who had reached SVR had their initial levels of IP-10 below that of non-responders. The prognostic level of IP-10 was detected, above which the likelihood of ending up at SVR in case of AVT with pegIFN- $\alpha$ and ribavirin was questionable: $\leq 403 \mathrm{pg} / \mathrm{ml}$ for G1 and $\leq 433 \mathrm{pg} / \mathrm{ml}$ for G2 or G3. In 18 patients who were given triple AVT - peglFN- $\alpha$ + ribavirin + viral proteases inhibitors (SVR - $77.7 \%$ ) the initial levels of IP-10 at various outcomes of AVT were the same. Therefore, in case of $\mathrm{CHC}$, the levels of blood IP-10 are elevated and depend on cytolysis activity and the degree of hepatic fibrosis. The levels of $\mathrm{IP}-10$ protein in case of $\mathrm{CHC}$ may be used as a predictor regarding the standard AVT outcomes.

Key words: chronic hepatitis $C$, chemokines, antiviral therapy, prognosis

Определялось клиническое значение сывороточных уровней интерферон- $\gamma$ индуцированного протеина (IP10) в прогнозировании устойчивого вирусологического ответа (SVR) на противовирусную терапию (ПВT) хронического вирусного гепатита С (ХВГС) у 107 больных (50 женщин и 57 мужчин), средний возраст - 43,0 1,1 лет. У 75 был диагностирован генотип 1 HCV (G1), у 32 пациентов - не-1 генотип HCV (G2 или G3). Содержание IP-10 в сыворотке крови определяли методом ELISA. Содержание IP-10 в крови больных ХВГС значительно превышало показатели здоровых и зависело от активности аминотрансфераз и стадии фиброза печени. Стандартная ПВТ препаратами ПегИФН- $и$ и рибавирином у 52 пациентов с G1 (SVR 54,9 \%) и 27 - с G2 или G3 (SVR 75 \%) показала, что у больных, достигших SVR, исходный уровень IP-10 был ниже, чем у нон-респондеров. Определен прогностический уровень IP-10, выше которого вероятность достижения SVR при ПВT ПегИФН- $\alpha$ и рибавирином сомнительна: $\leq 403$ пг/мл при G1 и $\leq 433$ пг/мл при G2 или G3. У 18 больных, получивших тройную ПВТ: ПегИФН- $/$ рибавирин + ингибиторы вирусных протеаз (УВО - 77,7 \%), исходное содержание IP-10 при разных результатах противовирусной терапии не различалось. Таким образом, при ХВГС уровень в крови IP-10 повышен и зависит от активности цитолиза и выраженности стадии печеночного фиброза. Содержание белка IP-10 при ХВГС может быть использовано в качестве предиктора исходов стандартной ПВТ.

Ключевые слова: хронический вирусный гепатит С, хемокины, противовирусная терапия, прогноз

C hronic hepatitis $\mathrm{C}(\mathrm{CHC})$ is rated among the top socially meaningful issues in medicine nowadays. Hepatitis $\mathbf{C}$ virus is believed to have infected $130-170 \mathrm{mln}$ people worldwide, and it is listed as the cause behind 350,000-500,000 deaths annually [23]. CHC is also named among the major causes for hepatic cirrhosis and hepatocellular carcinoma as well as HCV-infection, and prevails among other etiological factors resulting in liver transplantation [6].

Antiviral therapy (AVT) for $\mathrm{CHC}$ has gone through significant evolution - monotherapy with interferon- $\alpha$ $(\mathrm{IFN}-\alpha)$ medications in the 1980s, arrival of ribavirin
(RBV), pegylated IFNs (PeglFN), and finally combination with direct-acting antiviral (DAA) drugs. The year 2014 witnessed non-interferon schemes coming into clinical practice. Improved AVT modes have led to a significant increase in the rate of sustained virologic response (SVR) $[2,10,11,17]$. Yet, the newer generation medications are extremely costly, which imposes certain limitation on their use, and which keeps IFN- $\alpha$ medications still relevant. Given this, choice of optimal treatment modalities in view of all therapy predictors comes out as of crucial importance. The well-known predictors for SVR at a standard AVT include HCV genotype, viremia level, as well as the carrier factors, namely the stage of hepatic fibrosis, 
the race, hepatic steatosis, insulin resistance (if present), IL-28B genotype, the blood levels of vitamin D, and (IP-10) $\gamma$-interferon-inducible protein, CXCL10 [4, 15]

IP-10 protein (CXCL10/IP-10) is a chemokine playing an important role in eliminating HCV infection. The protein is produced by various cells - hepatocytes, T-lymphocytes, natural killers (NK), and monocytes [9, 26]. IP-10 is produced by hepatocytes as a response to hepatitis $\mathrm{C}$ infection [22], while the circulating levels of protein correlate with the expression of IP-10 matrix RNA (mRNA) in the hepatic tissue [3]. Involved in immune inflammation, IP-10 as a chemokine attracts to the hepatic tissue not so many of neutrophils but, more actively, T-lymphocytes, NKs and monocytes $[1,16]$.

In cases of acute hepatitis $\mathrm{C}$, patients with higher plasma levels of IP-10 were not capable of spontaneous HCV clearance and were viewed as candidates for early antiviral therapy, while the low levels of protein were associated with potential recovery [8]. In patients suffering from $\mathrm{CHC}$ who were co-infected with HIV, the initial level of IP. $10>400 \mathrm{pg} / \mathrm{ml}$ was a highly specific and sensitive predictor for SVR (sustained virologic response) in case of standard AVT [19]. High blood levels of IP-10 in case of CHC are also known to be in correlation with the viremia level and the severity of hepatic fibrosis [20]. The issue related to the inefficiency of IP-10 hyperproduction for elimination of HCV still remains unclear. There reports available telling about possible limitation of T-cells' functional activity under continuous impact that chronic HCV infection has on immunity due to CXCL10/IP-10 circulating in the patients' blood in its alternated type (antagonistic for the receptor) [5, 18].

Clarifying the role played by increased production of IP-10 in the clinical presentation of $\mathrm{CHC}$ may prove useful in terms of developing forecast for the disease course. Detecting of IP-10 levels in patients with $\mathrm{CHC}$ may serve an important predictor for selecting not only an efficient yet also a cost-efficient AVT mode.

Aim of study: to identify the clinical values for IP-10 serum levels in terms of forecasting sustained virologic response to antiviral therapy offered to patients with chronic hepatitis $\mathrm{C}$

Material and Methods. 107 patients with $\mathrm{CHC}$ were studied ( 50 females and 57 males; mean age $-43.0 \pm 1.1$ ). Most of them (75) were infected with genotype (G) $1 \mathrm{HCV}$ (G1): 73 patients $-1 \mathrm{~b}, 2$ patients $-1 \mathrm{a}+1 \mathrm{~b}$. Non-1 genotype HCV ( $\mathrm{G} 2$ or 3 ) was diagnosed in 32 patients: 25 had Genotype 3 of the virus, while another 7 revealed genotype $2 \mathrm{HCV}$. The level of viral load was measured in IU/ $\mathrm{ml}$, the mean value for viremia was $\lg 6.6 \pm 0.1$. The study included no patients displaying signs of being infected with hepatitis B virus - HBsAg, HBV-DNA. The average AIAT activity was $82.98 \pm 8.11 \mathrm{U} / \mathrm{l}$, AspAT - 64.72 \pm 5.54 $\mathrm{U} / \mathrm{I}$. All the patients underwent liver elastometry (SuperSonic Imagine Aixplorer, France); advanced stages of fibrosis ( $\mathrm{F} 3$ and $F 4$, METAVIR) were detected in 32 patients $(29.9 \%)$, while complete hepatic cirrhosis $(\mathrm{HC})$ was diagnosed in 16 patients. All the patients with $\mathrm{HC}$ had their liver function compensated; patients with suband decompensated pathology were not included in the study.

A standard AVT with PegIFN and ribavirin medications (PegIFN/RBV) was given to 52 patients with G1 HCV, and to 27 patients with non-1 genotype. The standard therapy course was 48 weeks for genotype $1 \mathrm{HCV}$, and 24 weeks - for G 2 or 3 . The medication doses were administered subject to the current standards [7]. 18 patients with Genotype $1 \mathrm{HCV}$ were given the triple therapy mode - pegIFN $-\alpha+$ ribavirin + viral protease inhibitors (while 12 patients were given telaprevir, 3 - boceprevir, 3 -simeprevir). In the group of cases with hepatitis $C$ that were given three antiviral drugs, 7 of the patients had previous history of failed treatment with the standard combination of antiviral medications.

The control group included 18 basically healthy persons with no markers of viral hepatitis.

The IP-10 levels in the blood serum were identified with the ELISA method employing commercial test systems (Bioscience, Austria).

The statistical processing of the results was done using the software Microsoft Office Excel 2007 with Attestat 10.5.1, IBM SPSS Statistics 21 incorporated. The values for the blood levels of IP-10 showed abnormal distribution, for which reason they were presented as a median $(\mathrm{Me})$ with an interquartile range $\left(25^{\text {th }}\right.$ and $75^{\text {th }}$ percentiles); the two groups were compared employing Mann-Whitney U-test. The differences were accepted as statistically significant at $p<0.05$. The correlation analysis was performed with Spearman rank correlation evaluated $-r_{s}$. The ROC-analysis (Receiver Operator Characteristic) with ROC curve built was used to calculate the optimal value of the cutoff threshold.

Results and Discussion. The blood levels of IP-10 in patients with $\mathrm{CHC}$ was significantly above the similar indices obtained from the control group: 291 (229-435) pg/ $\mathrm{ml}$ vs. 170.5 (145; 184.5) pg/ml; $\mathrm{p}<0.0001$ (Fig. 1). These outcomes were predictable and matched the data obtained earlier [5, 12, 13, 20, 21]. The HCV genotype had no impact on the IP-10 levels in blood; the protein values in the groups of patients with genotype 1 and non-1 HCV were no different either. Hyperproduction of IP-10 at $\mathrm{CHC}$ is initiated via the stable influence that HCV has on the patient's immunity. The link between the level of viremia and IP-10 in the blood of patients with $\mathrm{CHC}$ was reported by A. I. Romero et al. [20]. Our study revealed a positive weak correlation between the viral load level and the blood IP-10 $\left(r_{s}=0.24 ; p=0.032\right)$. An investigation of the dependence between the serum levels of IP-10 and the biochemical features of hepatitis activity - serum aminotransferases, revealed a weak yet reliable direct correlation between the aminotransferases' activity indicators: respectively, with the AIAT activity $-r_{\mathrm{s}}=0.23(p=0.035)$ and the AspAT activity $-r_{s}=0.29(p=0.007)$. A number of earlier research showed a connection between the histological activity index (HAI) in the liver tissues and the IP-10 levels at $\mathrm{CHC}$ $[19,24]$, while the hepatocytes expressing CXCL10/IP-10 in hepatic lobules were prevailing in the inflammation areas [26]. This serves a logic proof to the dependence that we revealed between protein levels and cytolytic activity.

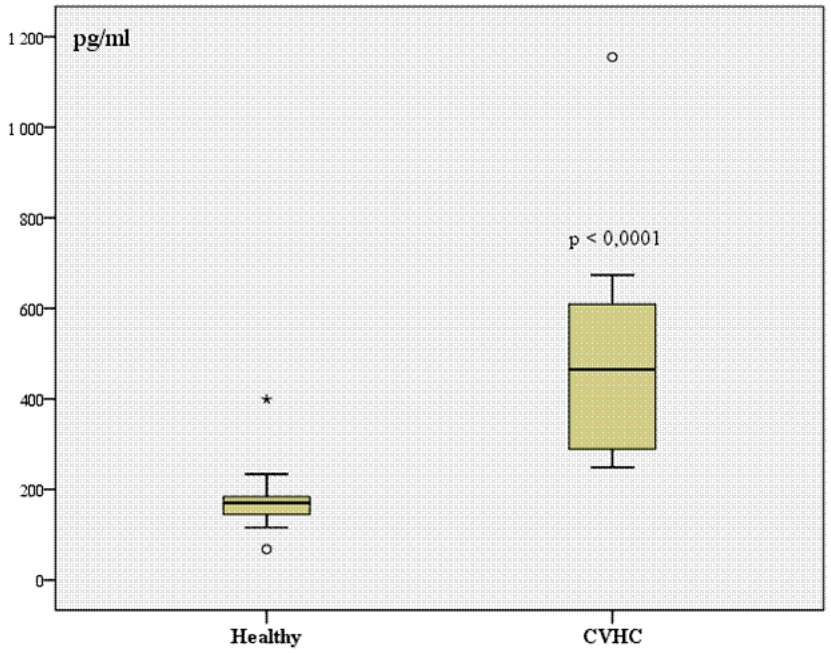

Fig. 1. Blood levels of IP-10 in patients with chronic viral hepatitis C 
Top high serum levels of IP-10 were detected in patients with advanced stages of fibrosis (F 3-4) - 435 $(283 ; 656) \mathrm{pg} / \mathrm{ml}$ (Fig. 2). The serum levels of IP-10 are known to have shown correlation not with the histological activity index (HAl) alone but also with the fibrosis stage in patients with Genotype $1 \mathrm{HCV}[19,24]$. Besides, we found a correlation between the blood levels of IP-10 and the fibrosis stage on METAVIR $-r_{s}=0.373$ $(p=0.0009)$. The negative impact that IP-10 has on the course of HCV infection was described by A. Casrouge et al. [5]. They noted that the serum IP-10 in case of CHC is in its antagonistic type that may change the normal interaction with the CXCR3 receptor thus disturbing the transmission of the intracellular signal. The antagonistic type of CXCL10/IP-10 is mediated by dipeptidyl-peptidase IV (DPP4, CD26), which leads to the growth of the number of deficient types of chemokines that potentiate liver tissue infiltration with non-specific effector cells, hepatocyte lesion, and activation of stellate cells inducing fibrogenesis.

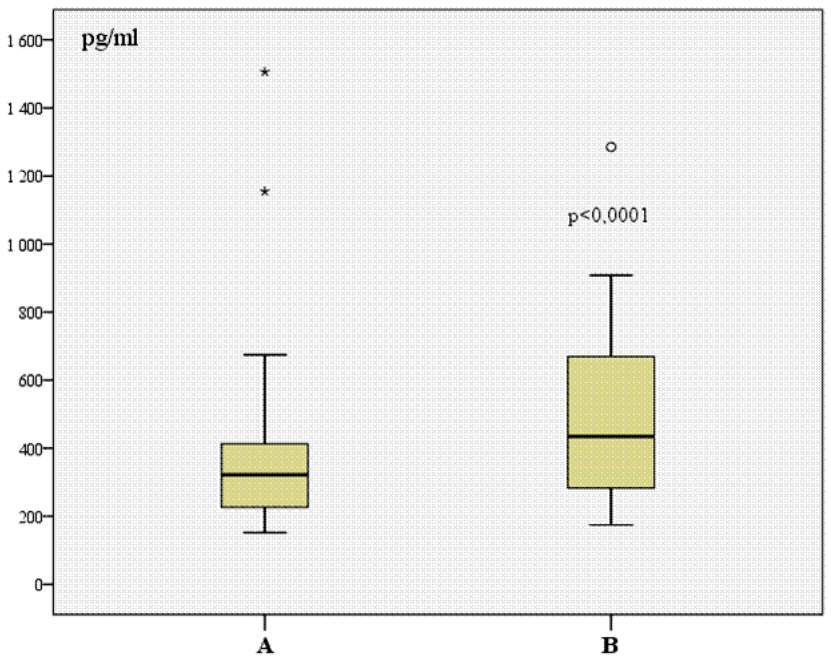

Fig. 2. Blood level of IP-10 protein in patients with chronic hepatitis C: A - fibrosis stage F 0-2; B - fibrosis stage F 3-4

The Table offers a view on the levels of the IP-10 levels at the start of AVT in patients with various treatment modes and outcomes. The standard AVT with PegIFN/RBV was given to 52 patients with Genotype 1 HCV (SVR was achieved in $55.7 \%$ of cases). All the patients that reached SVR had their initial levels of IP-10 prior to the therapy lower than in non-responders. The prognostic IP-10 levels for patients with G1 (above which the likelihood of reaching SVR under a standard AVT mode was questionable) was $403 \mathrm{pg} / \mathrm{ml}$. The AUC (Area Under Curve) index was 0.72 , which proved good clinical reliability. At the same time the odds ratio (OR) was 6.24 (1.7522.17 ) at $p=0.0047$. Our study confirms the predictor role of lower initial levels of IP-10 in terms of reaching SVR in case of employing PegIFN/RBV to treat patients with $\mathrm{CHC}$ G1. M. Zeremski et al., for instance, reported that the serum IP-10 levels median prior to the start of treatment given to patients with hepatitis $\mathrm{C}$ co-infected

References

1. Arsentieva N. A., Semenov A. V., Tutolyan A. A. Role of polymorphism of cytokine genes in viral hepatitis C. Infekciya $i$ immunitet - Infection \& Immunity. 2012;2(4):687-698.

2. Afdhal N., Zeuzem S., Kwo P., Chojkier M., Gitlin N. et al. ION-1 Investigators. Ledipasvir and sofosbuvir for with HIV and who further reached SVR, was much lower than in those who later proved to be non-responders [25]. Similar outcomes were yielded after giving PegIFN/RBV treatment to patients with $\mathrm{CHC}$ with no HIV $[12,14,20]$.

Table

Blood IP-10 levels $(\mathrm{pg} / \mathrm{ml})$ in patients with $\mathrm{CHC}$ undergoing various AVT schemes, prior to start of treatment, Me (Q1-Q3)

\begin{tabular}{|l|c|c|l|}
\hline \multicolumn{1}{|c|}{$\begin{array}{c}\text { Groups } \\
\text { of patients }\end{array}$} & $\begin{array}{c}\text { SVR } \\
\text { presence }\end{array}$ & $\begin{array}{c}\text { Lack } \\
\text { of SVR }\end{array}$ & $\begin{array}{c}\text { Reliability } \\
\text { of differ- } \\
\text { ence }\end{array}$ \\
\hline $\begin{array}{l}\text { Genotype 1: } \\
\text { PegIFN/RBV } \\
(n=52)\end{array}$ & $\begin{array}{c}249 \\
(227 S-290) \\
(n=29)\end{array}$ & $\begin{array}{c}433 \\
(237 S-606)\end{array}$ & $p=0.002$ \\
$(n=23)$ & \\
\hline $\begin{array}{l}\text { Genotype 1: } \\
\text { PegIFN/RBV } \\
+ \text { proteases' } \\
\text { inhibitors } \\
(n=18)\end{array}$ & $\begin{array}{c}288.5 \\
(219 S-606)\end{array}$ & $\begin{array}{c}352.5 \\
(234.5 S-561.5)\end{array}$ & $p=0.43$ \\
\hline $\begin{array}{l}\text { Genotype } \\
2 \text { or 3: } \\
\begin{array}{l}\text { PegIFN/RBV } \\
(n=27)\end{array}\end{array}$ & $\begin{array}{c}277) \\
(n=2.5 S-370.5)\end{array}$ & $\begin{array}{c}(285 S-435) \\
(n=20)\end{array}$ & $p=0.009$ \\
\hline
\end{tabular}

During that, the prognostic value of the initial IP-10 levels in treating $\mathrm{CHC}$ employing the triple therapy mode remains basically unstudied.

To do so, we offered treatment to 18 patients suffering from $\mathrm{CHC}$ G1, where the treatment included a combination of PegIFN/RBV with viral proteases' inhibitors (11 patients were given telaprevir, 3 - boceprevir). SVR was achieved in 14 cases ( $77.7 \%)$; the initial IP-10 levels were not different in patients with differing outcomes of the AVT (see Table). It should be borne in mind that the group in question included 8 patients with a previous history of failed therapy based on PegIFN/ $\mathrm{RBV}$, as well as another 9 patients with advanced stages of fibrosis (F 3-4). IP-10, therefore, can not be taken as a predictor for reaching SVR in treating $\mathrm{CHC}$ cases with a combination of PegIFN/RBV and viral proteases' inhibitors.

The impact of IP-10 on SVR likelihood at G2 or G3 has basically never been studied. Only one study reflects some data on potential use of IP-10 as a prognostic criterion in such patients [14]. In our case SVR was detected in 20 patients of non- 1 genotype HCV (74\%). This category of patients with $\mathrm{CHC}$ reached SVR in case of the initial serum levels of IP-10 $\leq 433 \mathrm{pg} / \mathrm{ml}(A \cup C=0.8)$. Thus, identifying the levels of the IP-10 protein when selecting the most effective and yet cost-efficient AVT for $\mathrm{CHC}$ cases may be of importance. Low levels of IP-10, along with other predictors for SVR may be used to select the standard therapy mode - PegIFN/RBV.

Conclusions. Cases of $\mathrm{CHC}$ have higher levels of the blood IP-10 compared to healthy people. The IP-10 protein levels depend on the serum aminotransferases' activity and the severity of hepatic fibrosis. In patients with $\mathrm{CHC}$ the serum levels of the IP-10 protein may be used as a predictor for the outcomes of the standard antiviral therapy with PegIFN- $\alpha$ and ribavirin. untreated HCV genotype 1 infection. N. Engl. J. Med. 2014;370:1889-1898. doi: 10.1056/NEJMoa1402454

3. Askarieh G., Alsio A., Pugnale P., Negro F., Ferrari C. et al. Systemic and intrahepatic interferon-gammainducible protein $10 \mathrm{kDa}$ predicts the first-phase decline in hepatitis $\mathrm{C}$ virus RNA and overall viral 
response to therapy in chronic hepatitis C. Hepatology. 2010;51:1523-1530. doi:10.1002/hep.23509

4. Berg T., Andreoni P., Pol S., Roberts S., Younossi Z. et al. Predictors of virologic response with telaprevirbased combination treatment in HCV genotype 1 -infected patients with pri or peginterferon/ribavirin treatment failure: post-hoc analysis of the phase III Realize study. Hepatology. 2011;54:375A-376A.

5. Casrouge A., Decalf J., Ahloulay M., Lababidi C., Mansour $\mathrm{H}$. et al. Evidence for an antagonist form of the chemokine CXCL10 in patients chronically infected with HCV. J. Clin. Invest. 2011;121(1):308-317. doi: $10.1172 / \mathrm{JCl} 40594$

6. Deltenre P. Studies on the epidemiology of hepatitis $\mathrm{B}$ and $\mathrm{C}$ virus infections are still needed. J. Hepatol. 2015;62:1225-1227. doi: 10.1016/j.jhep.2015.01.011

7. EASL Recommendations on Treatment of Hepatitis C 2015 (Guidelines). J. Hepatol. 2015;63:199-236.

8. Grebely J., Feld J. J., Applegate T., Matthews G. V., Hellard $M$. et al. Plasma Interferon-gamma-Inducible Protein-10 (IP-10) Levels During Acute Hepatitis C Virus Infection. Hepatology. 2013;57(6):2124-2134. doi: 10.1002/hep.26263

9. Harvey C. E., Post J. J., Palladinetti P., Freeman A. J., Ffrench R. A. et al. Expression of the chemokine IP-10 (CXCL10) by hepatocytes in chronic hepatitis $C$ virus infection correlates with histological severity and lobular inflammation. J. Leukoc. Biol. 2003;74:360-369. doi: 10.1189/jlb.0303093

10. Hezode C., Fontaine H., Dorival C., Zoulim F., Canva V. et al. Effectiveness of telaprevir or boceprevir in treatment-experienced patients with HCV genotype 1 infection and cirrhosis. Gastroenterology. 2014;147:132142. doi: 10.1053/j.gastro.2014.03.051

11. Jacobson I. M., McHutchison J. G., Dusheiko G., Di Bisceglie A. M., Reddy K. R. et al. Telaprevir for previously untreated chronic hepatitis $\mathrm{C}$ virus infection. N. Engl. J. Med. 2011;364:2405-2416. doi: 10.1056/ NEJMoa1012912

12. Lagging M., Romero A. I., Westin J., Norkrans G., Dhillon A. P. et al. IP-10 predicts viral response and therapeutic outcome in difficult-to-treat patients with HCV genotype 1 infection. Hepatology. 2006;44:16171625. doi: $10.1002 /$ hep. 21407

13. Larrubia J. R , Larrubia J. R Calvino M Benito S. Sanz-de-Villalobos E. et al. The role of CCR5/CXCR3 expressing CD8+ cells in liver damage and viral control during persistent hepatitis $\mathrm{C}$ virus infection. J. Hepatol. 2007:47(5):632-641. doi: 10.1016/j.jhep.2007.04.009

14. Lee S., Varano J., Flexman J. P., Chengc W., Watsond M. W. et al. Decreased IP-10 and elevated TGF $\beta 1$ levels are associated with viral clearance following therapy in patients with hepatitis C virus. Dis. Markers. 2010;28:273-280. doi:10.3233/DMA-2010-0699

15. McHutchison J. G., Lawitz E. J., Shiffman M. L., Muir A. J., Galler G. W. et al. Peginterferon alfa-2b or alfa-2a with ribavirin for treatment of hepatitis $C$ infec- tion. N. Engl. Med. 2009;361:580-593. doi: 10.1056/ NEJMoa0808010

16. Neville L. F., Mathiak G., Bagasra O. The immunobiology of interferongamma inducible protein $10 \mathrm{kD}$ (IP-10): a novel, pleiotropic member of the $\mathrm{C}-\mathrm{X}-\mathrm{C}$ chemokine superfamily. Cytokine Growth Factor Rev. 1997;8:207219. doi: 10.1016/S1359-6101(97)00015-4

17. Pawlotsky J.-M., Feld J. J., Zeuzem S., Hoofnagle J. H. From non-A, non-B hepatitis to hepatitis $\mathrm{C}$ virus cure. J. Hepatol. 2015;62:S87-S99.

18. Rehermann $B$. Hepatitis $C$ virus versus innate and adaptive immune responses: a tale of coevolution and coexistence. J. Clin. Invest. 2009;119(7):1745-1754. doi: 10.1172/JCI67714

19. Reiberger T., Aberle J. H., Kundi M., Kohrgruber N., Rieger A. et al. IP-10 correlates with hepatitis $\mathrm{C}$ viral load, hepatic inflammation and fibrosis and predicts hepatitis $\mathrm{C}$ virus relapse or non-response in $\mathrm{HIV} / \mathrm{HCV}$ coinfection. Antivir. Ther. 2008;13(8):969-976.

20. Romero A. I., Lagging M., Westin J., Dhillon A. P., Dustin L. B. et al. Interferon (IFN)-gamma-inducible protein-10: association with histological results, viral kinetics, and outcome during treatment with pegylated IFN-alpha $2 \mathrm{a}$ and ribavirin for chronic hepatitis C virus infection. J. Infect. Dis. 2006;194:895-903. doi: $10.1086 / 507307$

21. Sisoev K A Chuhlovin A B Shachmanov D. M Zhdanov K. V., Tutolyan A. A. The profile of cytokines and chemokines in plasma of patients with chronic hepatitis C. Infekciya i immunitet - Infection \& Immunity. 2013;3(1):49-58. doi: 10.15789/2220-7619-2013-149-58

22. Thomas E., Gonzalez V. D., Li Q., Modi A. A., Chen W. et al. HCV infection induces a unique hepatic innate immune response associated with robust production of type III interferons. Gastroenterology. 2012;142:978988. doi: 10.1053/j.gastro.2011.12.055

23. WHO, Hepatitis C., Fact sheet N 164, Updated April 2014. Available from <http://www.who.int/ mediacentre/factsheets/fs164/en/ $>$.

24. You Ch. R., Park S.-H., Jeong S. W., Woo H. Y., Bae S. H. et al. Serum IP-10 Levels Correlate with the Severity of Liver Histopathology in Patients Infected with Genotype-1 HCV. Gut and Liver. 2011;5(4):506-512. doi: 10.5009/gnl.2011.5.4.506

25. Zeremski M., Markatou M., Brown Q. B., Dorante J., Cunningham-Rundles S. et al. Interferon gamma-inducible protein 10: a predictive marker of successful treatment response in hepatitis $\mathrm{C}$ virus/HIV-coinfected patients. Acquir. Immune Defic. Syndr. 2007;45(3):262268. doi: 10.1097/QAI.0b013e3180559219

26. Zeremski M. Petrovic L. M. Chiriboga L., Brown Q. B., Yee H. T. et al. Intrahepatic levels of CXCR3-associated chemokines correlate with liver inflammation and fibrosis in chronic hepatitis C. Hepatology. 2008;48:1440-1450. doi: 10.1002/hep.22500

\section{About authors:}

Geyvandova Natalia, MD, PhD, Professor, Department for Hospital Therapy; tel.: +79624452246; e-mail: ngeyvandova@yandex.ru Lipov Andrey, MD, Postgraduate Student, Department for Hospital Therapy; tel.: +79286507264; e-mail: andrey_lipov89@mail.ru Yagoda Alexander, MD, PhD, Professor, Head of Department for Hospital Therapy; tel.: +79064907330; e-mail: alexander.yagoda@gmail.com Frolova Anastasia, MD, Doctor of Functional Diagnostics; tel.: +79187472499; e-mail: nastyaboblova@mail.ru 